\title{
SOLAR POWER SUPPLY FOR REMOTE OBJECTS OF HISTORICAL HERITAGE IN MONTENEGRO
}

Dr Goran Radović*

Faculty of Architecture, University of Montenegro, Podgorica

Dr Vera Murgul

St.Petersburg State Polytechnical University, Saint-Petersburg, Russia

Dr Meri Cvetkovska

Faculty of Civil Engineering, Ss. Cyril and Methodius University in Skopje, Macedonia

Dr Ekaterina Aronova

loffe Physical-Technical Institute of the Russian Academy of Sciences, Saint-Petersburg, Russia

Dr Nikolay Vatin

St.Petersburg State Polytechnical University, Saint-Petersburg, Russia

The article evaluates the possibility of using solar energy for power supply of the historic buildings and structures in accordance with the current Protection of Cultural Heritage legislation of Montenegro. The article puts forward the options for architectural incorporation of solar power systems into the appearance of historic buildings and structures. The article also considers the ways of solar photovoltaic installation into a number of electrical systems. The optimization of the parameters of such systems based on the example of independent consumer with different power schedules has been carried out. The configuration of systems based on the results of the calculation both with one energy source (solar/diesel plant) and their combination is proposed in the article, the capital cost of the equipment has been estimated together with the cost of maintenance and parts replacement as well as the total discounted costs over the operation of the system.

Key words: Solar power, Photovoltaic systems, Energy efficiency, Reconstruction, Restoration, Heritage historical buildings

\section{INTRODUCTION}

Montenegro's historic objects of different time periods represent the national identity and culture of the country. In Montenegro the number of such objects accounts for 2578, 1980 of which are immovable objects. [01, 06]

Some of these objects are located in areas remote from power networks, which impedes their restoration, protection and maintenance. Connecting them to a centralized power system is quite expensive due to their difficult accessibility (many of them are located on islands and mountain slopes) and low electric power required (supplied to few households in the area). The autonomous power supply systems are seen as a solution to this problem. $[13,07,17,08,03,18,20]$

The goal of the study set involves the following tasks:

- Evaluate the possibility of using solar energy to power the historic buildings and structures in accordance with the legislation of Montenegro in the field of cultural heritage;

- Using the estimation, we would like to suggest options for incorporating solar power supply systems into the appearance of a historic object without damaging the architectural perception.

- Choose the best option for the configuration of an autonomous solar power supply system.

The analysis of income streams of solar radiation

In order to assess the feasibility of solar installations implementations the analysis of income streams of solar radiation on the differently inclined south oriented surfaces with geographic coordinates $42^{\circ}$ North latitude, $19^{\circ}$ East longitude has been conducted. Figure 1. 

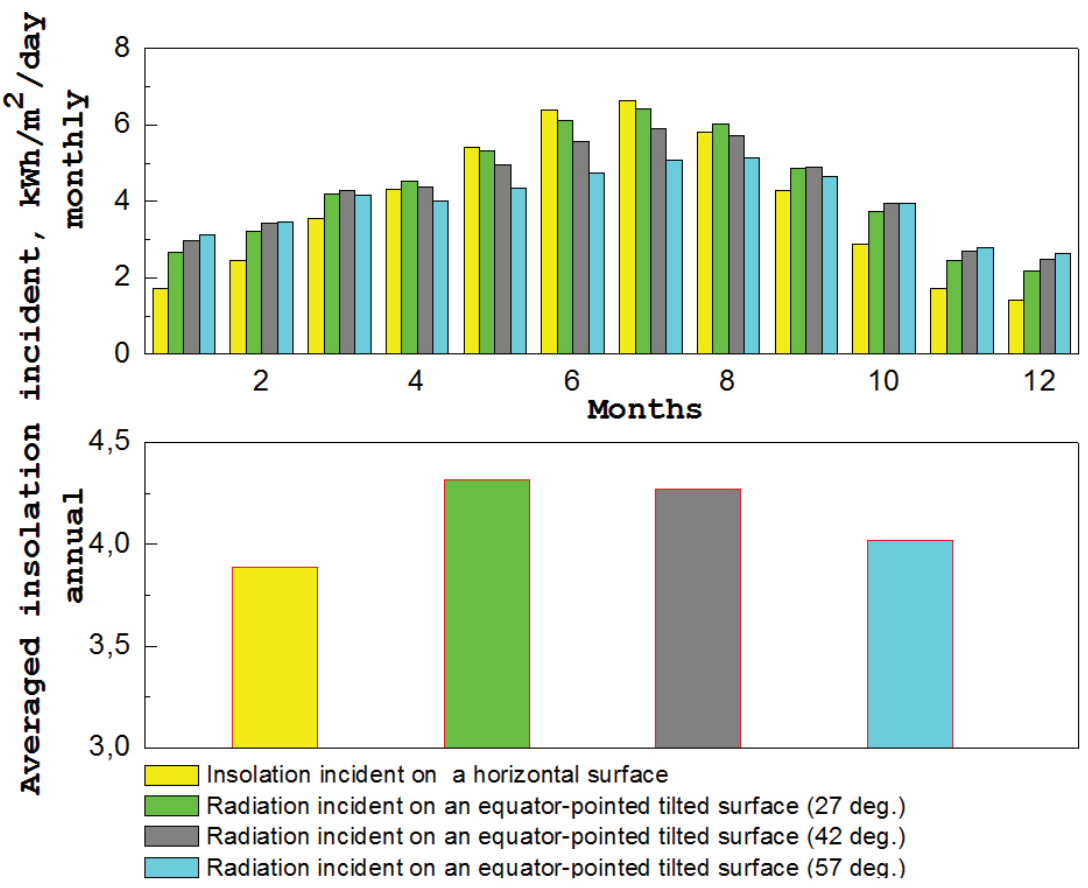

Figure 1: Radiation incident on differently inclined surfaces: horizontal, 27 deg., 42 deg., 57 deg.

The analysis of data leads to the following conclusions:

1. Maximum average annual solar energy input is on the inclined surface under the slope of $27^{\circ}$ to horizon, minimal input - is on the horizontal surface.

2. The most uneven input of solar radiation from month to month is equal to the surface inclined by $27^{\circ}$. Minimum solar energy income differences in summer and winter months are observed for the surface inclined by $57^{\circ}$.

The knowledge about the nature of the incoming solar radiation from one month to another one allows to choose the optimum angle of inclination of the surface for the most of energy effective and economy efficient schedule of electricity consumption. So for electricity supply mainly in the summer months is better to use photovoltaic modules, placed horizontally. To evenly load over the year it is advisable to place the modules at an angle of $57^{\circ}$ to the horizon. Data entry of incoming solar radiation allowed us to calculate the average monthly and average annual electricity generation by polycrystalline silicon photovoltaic modules with a rated efficiency $13 \%$, Table 1.

Table 1: Estimation of power generation by different oriented photovoltaic modules with nominal efficiency $13 \%, \mathrm{~kW} / \mathrm{m}^{2}$

\begin{tabular}{|c|c|c|c|c||}
\hline \multirow{2}{*}{ Period of time } & \multicolumn{4}{|c|}{ Angle of inclination photovoltaic module to horizon } \\
\cline { 2 - 5 } & $0^{\circ}$ & $27^{\circ}$ & $42^{\circ}$ & $57^{\circ}$ \\
\hline January & 6.97 & 10.68 & 12.01 & 12.65 \\
\hline February & 8.92 & 11.65 & 12.49 & 12.63 \\
\hline March & 14.35 & 16.93 & 17.25 & 16.72 \\
\hline April & 16.77 & 17.67 & 17.04 & 15.64 \\
\hline May & 21.76 & 21.44 & 19.95 & 17.53 \\
\hline June & 25.83 & 24.62 & 22.41 & 19.18 \\
\hline July & 25.90 & 25.08 & 23.01 & 19.77 \\
\hline August & 23.41 & 24.30 & 23.09 & 20.75 \\
\hline September & 16.73 & 19.03 & 19.11 & 18.17 \\
\hline October & 11.61 & 15.03 & 15.92 & 15.96 \\
\hline November & 6.75 & 9.56 & 10.49 & 10.88 \\
\hline December & 5.64 & 8.83 & 9.99 & 10.60 \\
\hline Year & 184.64 & 204,81 & 202.76 & 190.50 \\
\hline
\end{tabular}




\section{The analysis of the regulatory framework}

Montenegro's Ministry of Culture and the Office for the Pretection of Cultural Heritage (Ministarstvo kulture Crne Gore i Uprava za zaštitu kulturnih dobara) launched the project of reassessing cultural values. This project has been the largest one in the last decades. Currently this project is at the stage of completion. The purpose of the project is the formation of a highquality database containing full details of all previously recorded and newly identified cultural heritage objects. "The Law on the Protection of Cultural Heritage" ("Zakon o zaštiti kulturnih dobara") stipulates actions for the preservation of cultural heritage objects and protects them from improper reconstruction and ungrounded restoration. According to the law, the individual approach is given to each object while drafting the set of measures for their preservation. The projects are developed on the basis of the initial data from the Office for the Protection of Cultural Heritage ("Uprava za zaštitu kulturnih dobara") and are approved there.

The project implies the preservation of individual historic buildings and structures as well as of the surrounding environment that can be seen as the historic context for the immovable monuments of history and culture. Thus, the protection of cultural heritage is carried out both at the level of individual objects and the environmental level.

Photovoltaic systems can be divided into three categories in accordance with their position to a building, which is an energy recipient:
- Building-integrated photovoltaics (BIPV).

- Building attached photovoltaics (BAPV).

- Building-independent temporary photovoltaics constructions (BITPVC) [10].

The protection reasons tend to be a priority. Thus, the most suitable option for historic objects is building-integrated photovoltaics, which is a part of the building envelope construction or decorative and finishing materials (BIPV) [09, $12,14]$. Such a technique allows to integrate solar photovoltaic elements into the building enclosure and make them mostly invisible.

Also, it is possible to locate photovoltaic modules on blind roofing areas. Most suitable systems would be building-attached photovoltaics, technological fitting elements of envelope constructions (BAPV). Besides, photovoltaic modules can be located on adjacent buildings or on the ground near the object $[14,15]$.

Positioning of solar power supply systems into the category of temporary constructions was offered specifically for the power supply of unique objects: buildings of special architectural or historic interest. The use of building-independent temporary photovoltaic constructions (BITPVC) allows to turn to the original appearance of a historic building at any moment [10].

We prefer Building-integrated photovoltaics (BIPV) and "camouflage" methods, where we're using the principle of minimal impact on the original appearance of the building (Figure 2, 3).

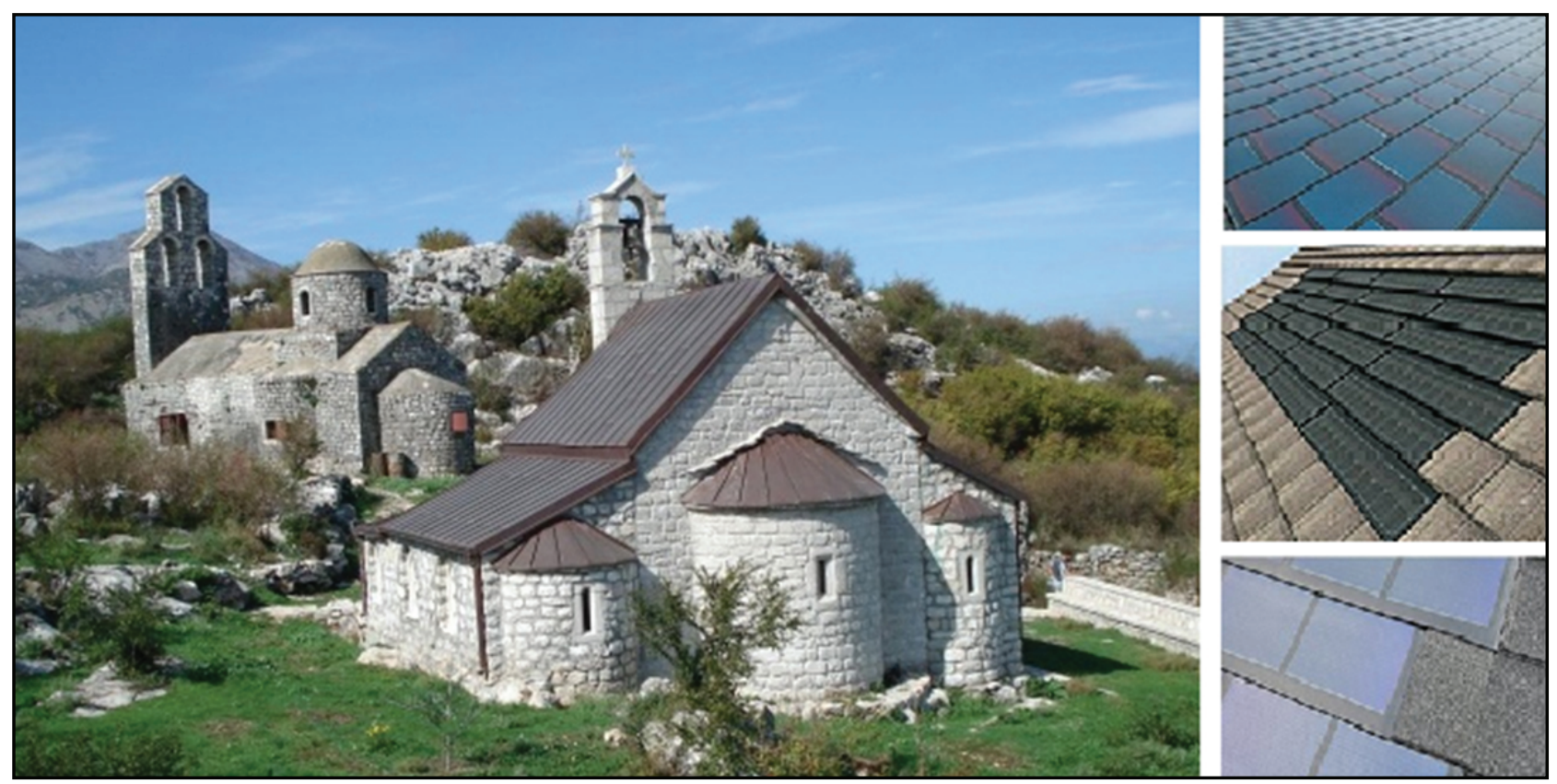

Figure 2: Building-integrated photovoltaics (BIPV). The Beska monastery, model 


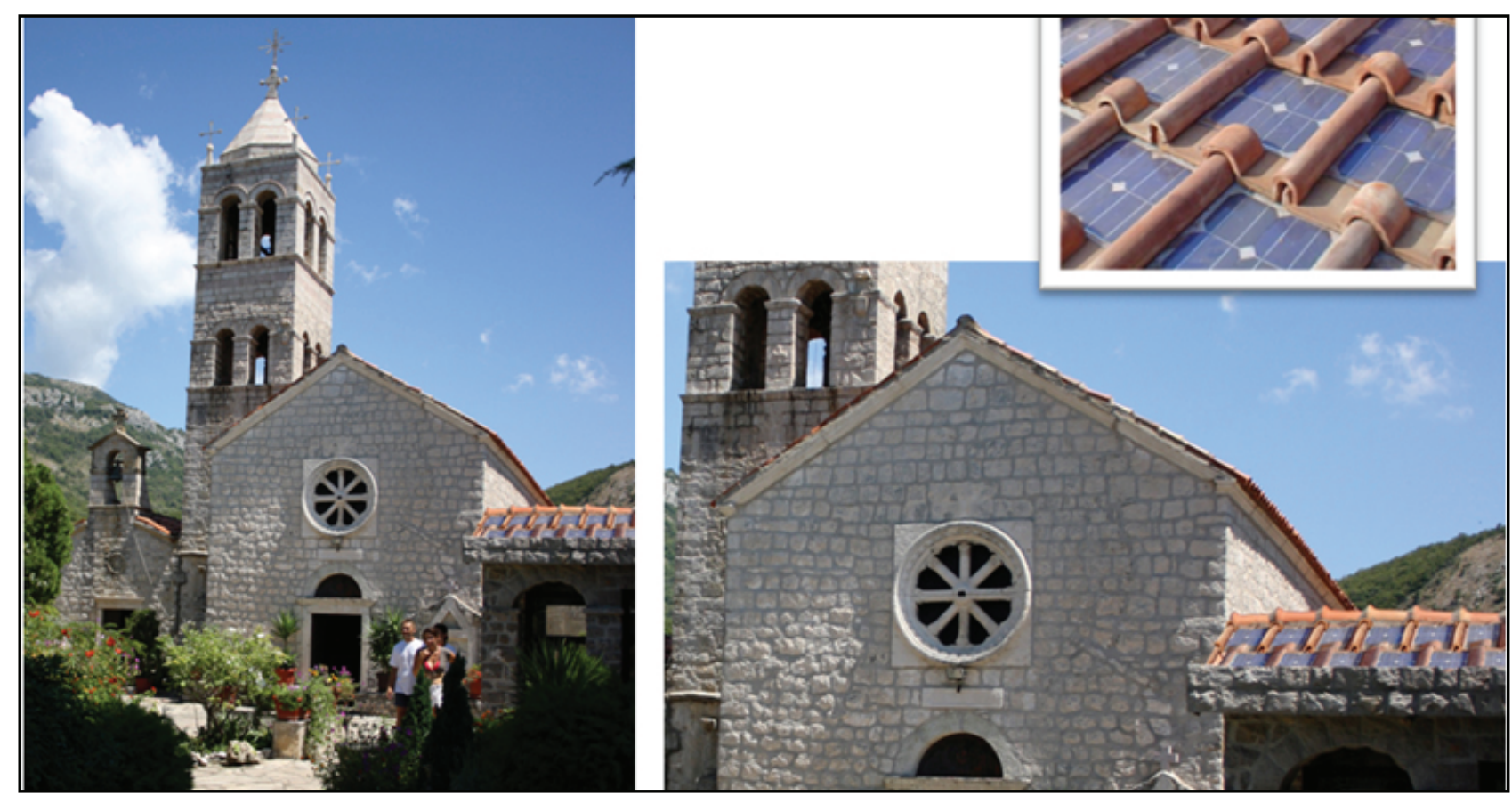

Figure 3: Monastery Rezevići. Model of photovoltaic elements integrated into the roof tiles

If this location is considered to be unacceptable, it is advisable not to place solar modules on an object, but near it.

\section{The calculation of parameters} for photovoltaic systems for the selected object of study - Starcevo monastery

The Starcevo monastery was chosen as the object of the study (Figure 4). When we discuss objects of cultural heritage, as a rule any change in the exterior of the building is unacceptable.

Currently the Starcevo monastery church has solar panels directly on the walls, which are constantly criticized by the specialists in the field of restoration.

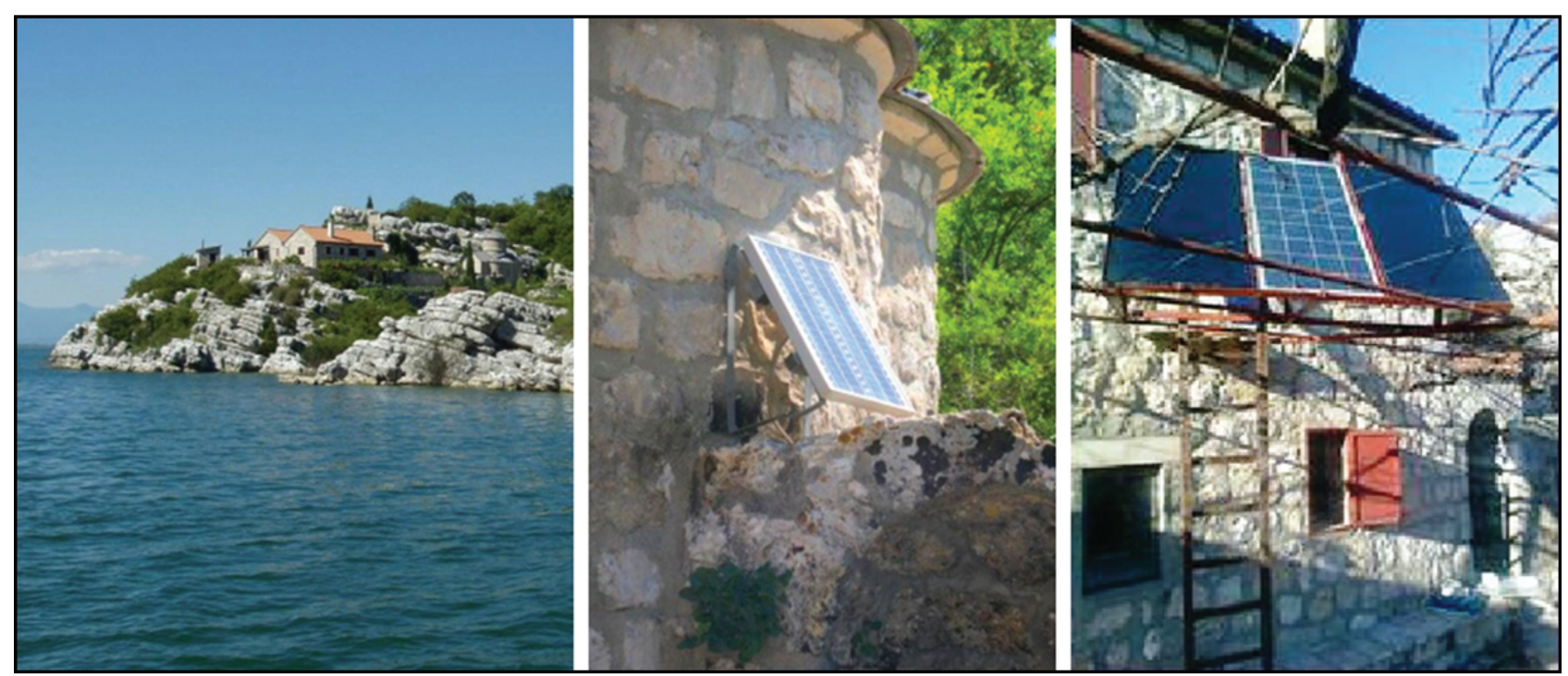

Figure 4: The Starcevo monastery with solar panels mounted on the church walls [16]

METHOD, CALCULATIONS AND RESULTS

\section{Method}

Simulation of different methods and optimization of the parameters of system elements was con- ducted with the use of a special computer program. Nowadays, the National Renewable Energy Laboratory (NREL) optimization computer model for distributed power,"HOMER," is widely applied. 
HOMER [04], the micro power optimization model, simplifies the task of evaluating designs of both off-grid and grid-connected power systems for a variety of applications. Model simulates the operation of a system by making energy balance calculations for each of the 8,760 hours in a year. For each hour, it compares the electric and thermal demand in the hour to the energy that the system can supply in that hour, and calculates the flows of energy to and from each component of the system. For systems that include batteries or fuel-powered generators (GEN), HOMER also decides for each hour how to operate the generators and whether to charge or discharge the batteries. Model performs these energy balance calculations for each system configuration that should be optimized. It then determines whether a configuration is feasible, i.e., whether it can meet the electric demand under the speci- fy conditions, and estimates the cost of installing and operating the system over the lifetime of the project. The system cost calculations account for costs such as capital, replacement, operation and maintenance, fuel, and interest. After simulating all of the possible system configurations, HOMER displays a list of configurations, sorted by net present cost (sometimes called lifecycle cost), that can be compared by system design options. If sensitivity variables are defined as inputs, HOMER repeats the optimization process for each sensitivity variable. After that displays optimal results depends on sensitive variables. Optimization criteria chosen were the minimum net present costs for the whole period of system's service. The limit considered was the minimum value of losses of energy in the system. [18-20] The costs of the elements in question are present in the Table 2.

Table 2: Costs of the system elements

\begin{tabular}{|c|c|c|c|c|}
\hline \multirow{2}{*}{ System elements } & \multicolumn{4}{|c|}{ Costs of the system elements, \$ } \\
\cline { 2 - 5 } & Capital & Replacement & $\begin{array}{c}\text { Operation } \\
\text { and maintenance }\end{array}$ & Fuel (I) \\
\hline Photovoltaic installation (1 kW) & 4000 & 2000 & 0 & --- \\
\hline Storage battery (1 unit) & 300 & 300 & 20 & --- \\
\hline Fuel-powered generators (1 kW) & 1500 & 1200 & 0.05 & 1.5 \\
\hline Converter (1 kW) & 1000 & 1000 & 100 & --- \\
\hline
\end{tabular}

When calculating the various structural schemes and combinations of parameters of elements in the system were considered.

1. $\mathrm{PV}$ modules + storage batteries (SB);

2. Fuel-powered generator + storage batteries;

3. PV modules + Fuel-powered generator + storage batteries.

As the optimized parameters were taken:

1. Peak power of solar PV installation varied from 1 to $5 \mathrm{~kW}$ with the step of $0,5 \mathrm{~kW}$.

2. The inclination angle of PV modules was: $27^{\circ}, 42^{\circ}, 57^{\circ}$.

3. The power of fuel-powered generator varied from 1 to $5 \mathrm{~kW}$ with the step of $0,5 \mathrm{~kW}$.

4. The number of storage batteries varied from 8 to 80 with the step of 8 .

5. Power of converter varied from $2 \mathrm{~kW}$ to 8 $\mathrm{kW}$ with the step of $2 \mathrm{~kW}$.

\section{CALCULATIONS AND RESULTS}

Lake Skadar Island is one of the most interesting applications of autonomous solar power plants in Montenegro. There are monasteries of $14-15^{\text {th }}$ centuries built on the islands. Today most of them have been restored, but only some of them are adapted to electric power. So, the oldest monasteries of Startsevo, Morachnik and Kom, the landmarks of Montenegro's culture and history, still do not have centralized power supply [01]. Traditionally, the monasteries have always been separate and independent, so solar power supply will enable them to keep their independence and will make life in monasteries more comfortable. The key consumer of the electrical energy in monastery are 5-7 monks permanently reside. Schedule power of such an object is a standard schedule for houses with the only one peak consumption in the evening around 18.00. The annual average daily consumption is $5 \mathrm{~kW} / \mathrm{h}$ per day, maximum possible peak consumption is $0.7 \mathrm{~kW} / \mathrm{h}$ 
Optimized calculated results for object (monastery) for the different slopes of incline of PV modules in solar installation are present in the Table 3.

Table 3: Optimal configurations of autonomous power supply system

\begin{tabular}{|c|c|c|c|c|c|c|c|c|c|c|}
\hline \multirow{2}{*}{\multicolumn{2}{|c|}{\begin{tabular}{|l|l|}
$\begin{array}{l}P V \\
\text { kW }\end{array}$ & GEN, kW \\
Power ratio \\
of $\mathrm{PV} \&$ Gen, \%
\end{tabular}}} & \multirow{2}{*}{$\begin{array}{l}\text { SB, } \\
\text { units }\end{array}$} & \multirow{2}{*}{$\begin{array}{l}\text { Conv., } \\
\text { kW }\end{array}$} & \multirow{2}{*}{$\begin{array}{c}\text { Capital, } \\
\$\end{array}$} & \multirow{2}{*}{$\begin{array}{l}\text { Operating } \\
\text { cost, \$/year }\end{array}$} & \multirow{2}{*}{ Total, \$ } & \multirow{2}{*}{$\begin{array}{l}\text { COE, } \\
\$ / k W h\end{array}$} & \multirow{2}{*}{ El los, \% } & \multicolumn{2}{|c|}{ Generator } \\
\hline & & & & & & & & & Oil, Itr & Time, $\mathrm{h}$ \\
\hline \multicolumn{11}{|c|}{ Parameters of autonomous power supply system elements for PV modules tilted angle $27^{\circ}$} \\
\hline 1.5 & 1 & \multirow{2}{*}{8} & \multirow{2}{*}{2} & \multirow{2}{*}{11900} & \multirow{2}{*}{944} & \multirow{2}{*}{23966} & \multirow{2}{*}{1.027} & \multirow{2}{*}{7.65} & \multirow{2}{*}{168} & \multirow{2}{*}{528} \\
\hline 79 & 21 & & & & & & & & & \\
\hline 3.5 & & \multirow{2}{*}{16} & \multirow{2}{*}{2} & \multirow{2}{*}{20800} & \multirow{2}{*}{931} & \multirow{2}{*}{32704} & \multirow{2}{*}{1.402} & \multirow{2}{*}{51.4} & & \\
\hline 100 & 0 & & & & & & & & & \\
\hline \multicolumn{11}{|c|}{ Parameters of autonomous power supply system elements for PV modules tilted angle $42^{\circ}$} \\
\hline 1.5 & 1 & \multirow{2}{*}{8} & \multirow{2}{*}{2} & \multirow{2}{*}{11900} & \multirow{2}{*}{943} & \multirow{2}{*}{23950} & \multirow{2}{*}{1.027} & \multirow{2}{*}{6.83} & 163 & 527 \\
\hline 80 & 20 & & & & & & & & 103 & 522 \\
\hline 3.5 & & & & & & & & & & \\
\hline 100 & 0 & 10 & 2 & 20000 & 901 & 02104 & 1.402 & 01.4 & & \\
\hline & Param & ters of & utonomou & s powers & upply system & lements fc & PV modu & es tilted an & $57^{\circ}$ & \\
\hline 1.5 & 1 & 8 & 2 & 11900 & 963 & 24208 & 1.038 & 4.12 & 173 & 542 \\
\hline 78 & 22 & & & & & & & & & \\
\hline 3.5 & & 16 & 2 & 20800 & 931 & 32704 & 1.402 & 48.9 & & \\
\hline 100 & 0 & & & & & & & & & \\
\hline & Parame & rs of a & onomous & power sup & ply system ele & ments bas & d on fuel- & owered g & erators & \\
\hline & 1 & 8 & 2 & 5900 & 2275 & 34986 & 1.5 & 0 & 829 & 2513 \\
\hline
\end{tabular}

The analysis of calculated results, shown in the Table 3 allows for the following conclusions:

1. Due to relatively small energy consumption of the monastery the slope of inclination of $\mathrm{PV}$ modules towards the horizon doesn't influence the optimum system configuration.

2. From the technical and economical point the optimal is the configuration of the system based on combine use of solar installation and Fuel-powered generator; the net present costs for the whole service period of the system in this case are equal.

3. For this schedule of energy consumption the possible system configuration is the system with only solar installation, but the net present costs in this case will be 1.5 times higher than costs of system with combine usage of solar installation and Fuel-powered generator.

4. The use of the system of only one electrical energy source, solar installation or Fuelpowered generator, leads to the similar costs of the system, the losses in both cases are close to $50 \%$.
5. Thus, optimal parameters of autonomous power supply system elements for monastery: solar system power is $1.5 \mathrm{~kW}$ with $\mathrm{PV}$ modules tilted angle $42^{\circ}$, area 11.5 square meter, Fuel-powered generator power is 1 $\mathrm{kW}$, storage battery number is 8 units, converter power is $2 \mathrm{~kW}$.

\section{Night lighting of remote objects}

Night lighting of remote objects, which are at the same time view points in the coastal area, will stimulate the promotion of historic places and attract attention to the historic and cultural monuments in Montenegro. Figure 5 shows St. Demetrius' Church, located in the Haj-Nehaj fortress, and predating the fortress itself.

A temporary energy-supply covering can be erected in order to light and protect a historic object from precipitations during restoration. Moreover, the covering can be used constantly as a measure to conserve a historic and cultural monument. 


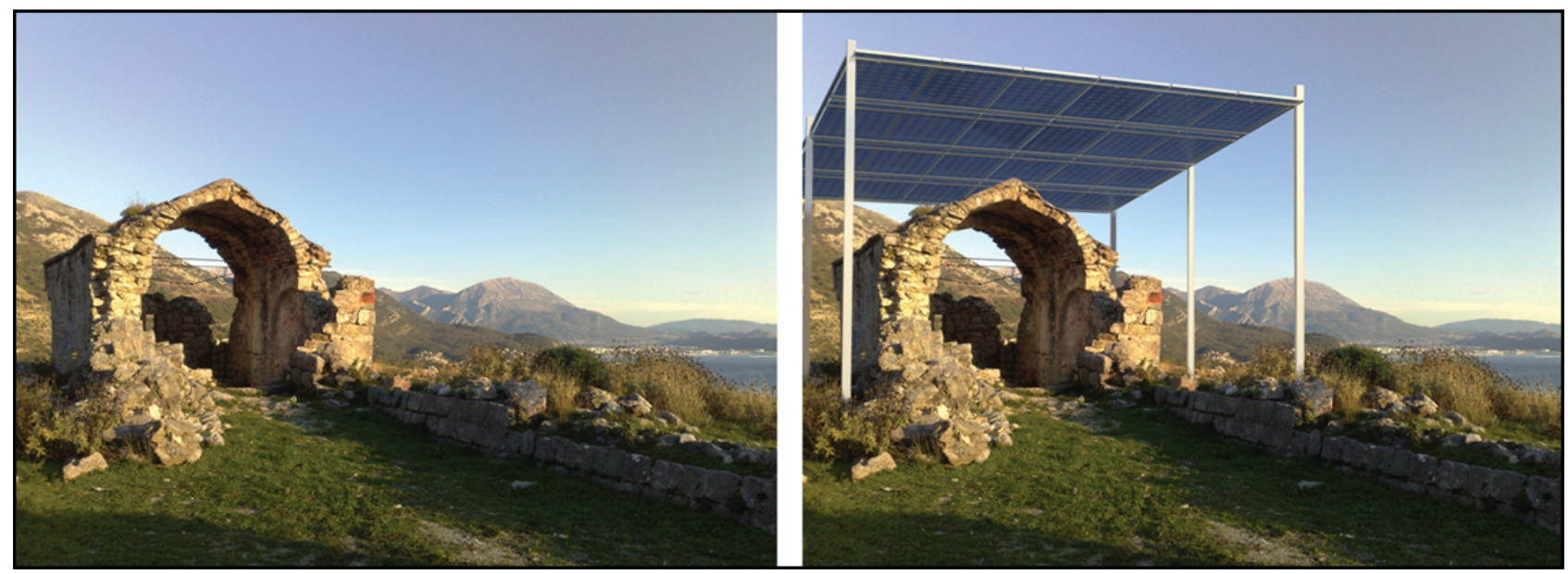

Figure 5: St.Demetrius' Church. Model of building-independent temporary photovoltaic construction (BITPVC)

In the present research we used flint solar modules. Their hard framework allows to produce a

tions. The solar energy, accumulated in the day portable covering with metallic posts and sec-
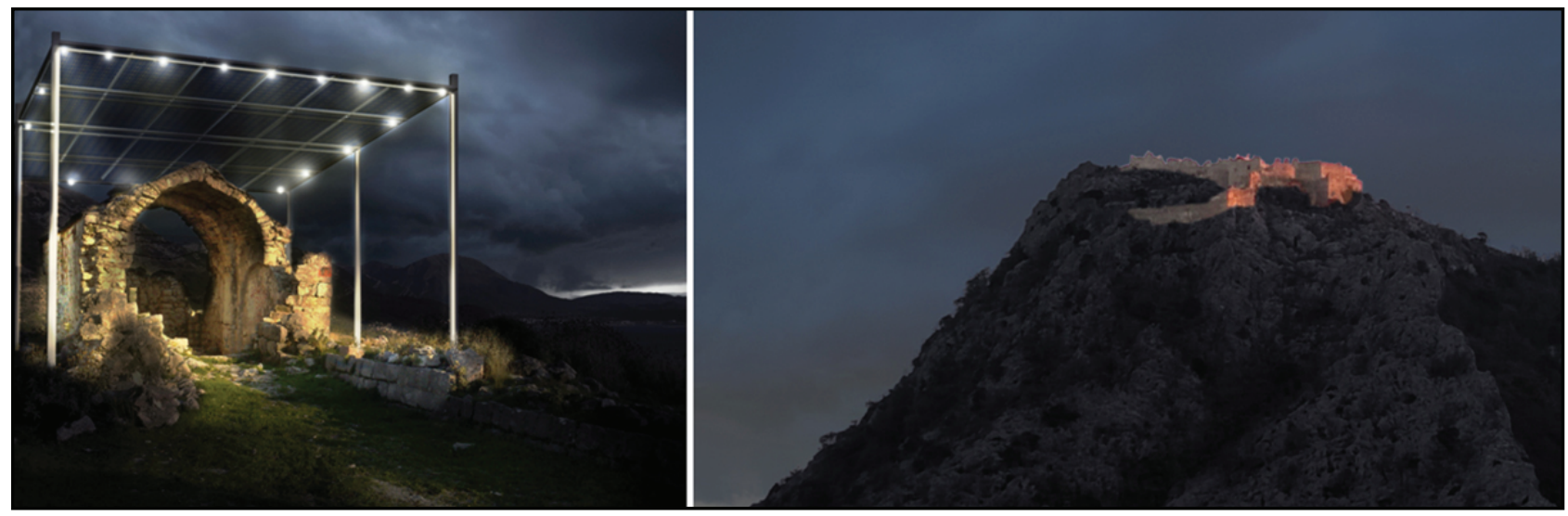

Figure 6: Model of night lighting of St. Demetrius' Church and Nehaj Fortress

Figure 7 shows the St.Nedelja Church. The small island is located near Petrovac resort town. With no lighting at night, the island and church are lost in darkness. Solar panels located on the Southern slope of the island could provide the object with the system of night decorative lighting.

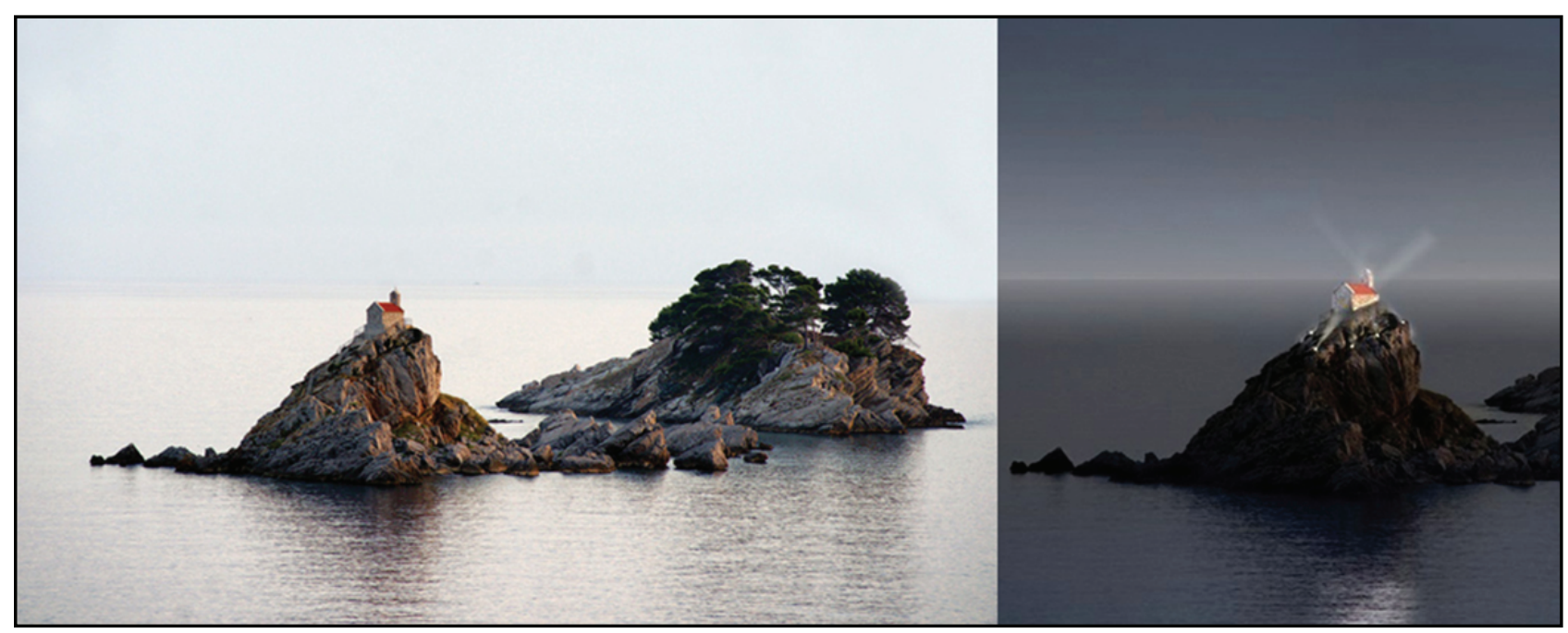




\section{CONCLUSION}

The analysis of Montenegro's legislature protecting the cultural heritage objects confirmed the possibility to use alternative energy sources to provide historic buildings with energy in compliance with main principles of protecting historic and cultural monuments. In the situation when the appearance of buildings can not undergo changes, it is advisable to use integrated photovoltaic elements or fully refuse to use solar power supply systems in favour of protection and conservation of the authentic historic environment.

The results of calculations revealed the expediency of combined use of solar installations and Diesel engine generators for achievement of economical and energy efficient electricity supply of autonomous objects of different power.

\section{REFERENCES}

1) G. Radović: Istorija arhitekture Crne Gore, Podgorica: Skripta, Arhitektonski fakultet Univerziteta Crne Gore (2006)

2) Davidsson, H., Perers, B., Karlsson, B (2012): System analysis of a multifunctional $\mathrm{PV} / \mathrm{T}$ hybrid solar window, Solar Energy, Vol. 86 (3), pp 903-910

3) Elistratov, V., Kudryasheva, I., Miroshnikova, J. (2014): Enumeration of system efficiency into tariff of renewable energy objects, Applied Mechanics and Materials, Vol. 680, pp. 517-523.

4) http://homerenergy.com, retrieved on November 8th, 2014

5) http://www.academia.edu/5003525/Zdravko_ Gagovic, retrieved on November 8th, 2014

6) http://www.ministarstvokulture.gov.me/ministarstvo, retrieved on November 8th, 2014

7) Leskovar, V.Z., Premrov, M. (2012): Design approach for the optimal model of an energy-efficient timber building with enlarged glazing surface on the south façade. Journal of Asian Architecture and Building Engineering, 11 (1), pp. 71-78.

8) Leskovar, V.Ž., Premrov, M., Kuzman, M.K. (2012): Energy-Efficient Renovation Principles for Prefabricated Timber-Frame Residential Buildings [Energetski učinkovita načela obnove montažnih stambenih zgrada s drvenim okvirom], Drvna Industrija, 63 (3), pp. 159-168.

9) Moschella, A., Salemi, A., Lo Faro A, Sanfilippo, G., Detommaso, M., Privitera, A. (2013): Historic Buildings in Mediterranean Area and
Solar Thermal Technologies: Architectural Integration vs Preservation Criteria, Energy Procedia, Vol. 42, pp. 416-425

10) Murgul, V. (2014): Solar energy systems in the reconstruction of heritage historical buildings of the northern towns (for example Sankt-Petersburg), Journal of Applied Engineering Science, Vol. 12 (2), pp 121-128

11) Norton, B., Eames, P.C., Mallick, T.K., Huang, M.J., McCormack, S.J (2011): Enhancing the performance of building integrated photovoltaics, Solar Energy, Vol 85, pp. 1629-1664.

12) Polo López C. S., Frontini, F. (2014): Energy efficiency and renewable solar energy integration in heritage historic buildings, Energy Procedia Vol. 48 pp. 1493 - 1502

13) Scheer, H. (1995): Solar energy's economic and social benefits, Solar Energy Materials and Solar Cells, Vol. 38, Issues 1-4, pp 555-568

14) Sibley, M., Sibley, Mar. (2013): Hybrid Green Technologies for Retrofitting Heritage Buildings in North African Medinas: Combining Vernacular and High-tech Solutions for an Innovative Solar Powered Lighting System for Hammam Buildings, Energy Procedia, Vol. 42, pp 718-725

15) Sozer H., Elnimeiri, M. (2007): Critical factors in reducing the cost of building integrated photovoltaic (BIPV) systems, Architectural Science Review, Vol. 50, pp. 115-121.

16) Stamatovich, B. (2010): Automaton recognition of doubly connected labyrinths with finite cyclic diameter, Programming and Computer Software, 36 (3), pp. 149-156

17) Vatin, N., Nemova, D., Tarasova, D., Staritcyna A. (2014): Increase of energy efficiency for educational institution building. Advanced Materials Research, Vols. 953-954, pp. 854-870.

18) Wong L.T., Chow W.K. (2001): Solar radiation model, Applied Energy, Vol. 69 (3), pp. 191-224.

19) Xuan, X., Jian-Hong, W., Stamatovic, B. (2014): Iterative selection of unknown weights in direct weight optimization identification. Mathematical Problems in Engineering, 2014, art. no. 572092

20) Žegarac Leskovar, V., Premrov, M. (2011): Design approach for the optimal model of an energy-efficient timber building with various glazing types and surfaces on the south façade, WIT Transactions on the Built Environment, 118, pp. 541-552.

Paper sent to revison: 27.05.2014.

Paper ready for publication: 12.12.2014. 